IRSH 59 (20I4), Special Issue, pp. I I 3-I 32 doi:I0.10I7/So0208590I 4000376 (C) 2014 Internationaal Instituut voor Sociale Geschiedenis

\title{
Free and Unfree Labour and Ethnic Conflicts in the Brazilian Transport Industry: Rio de Janeiro in the Nineteenth Century*
}

\author{
PAUlo CRUz TERRA \\ History Department of Campos, Federal University Fluminense \\ Campos dos Goytacazes Campus, Rua José do Patrocínio 77, \\ Centro CEP 28.010-385, Campos/RJ, Brazil
}

E-mail: poo3256@yahoo.com.br

\begin{abstract}
Over the course of the nineteenth century, major changes transformed the transport of people and freight in Rio de Janeiro, the capital of Brazil during this period. These transformations involved both technological change, as transport evolved first from carriages and carts to horse-drawn trams and then to electric trams, as well as economic developments, such as the establishment of the first tram companies, many of which became important vehicles for foreign capital to enter Brazil. Although there has been extensive research from various angles into the changes undergone by the city's transport sector, there remains, however, a significant lacuna in the existing literature: the workers involved in that sector. The aim of this article is to analyse the workforce of the urban transport sector in Rio de Janeiro in the nineteenth century, and to understand the labour that these workers provided, how they were affected by the transformations in the sector, and, at the same time, how they responded to those transformations. During this period, issues such as the connections between free and unfree labour, ethnic conflicts, and work regulation were very important in transport work in Rio de Janeiro, and they are explored in the text.
\end{abstract}

For at least the first half of the nineteenth century, black porters were key figures in the transport of people and freight in Rio de Janeiro. According to contemporary reports from travellers in Brazil, porters were responsible for providing various basic services in the carioca society of the time, including the transport of water, food, the sick and the dead, and the collection of waste, as well as for carrying out removals. They also played an important role in moving freight through the Customs House.

\footnotetext{
* This article is based on the doctoral research I conducted at Universidade Federal Fluminense,
} Brazil up until March 20I2. 
Jean-Baptiste Debret, who lived in Rio de Janeiro between I8I6 and I83 I, reported that to transport coffee there was a porter for each sack, with a foreman motivating the workforce with songs. ${ }^{\mathrm{I}}$ As well as carrying freight on their shoulders and on their heads, when transporting large volumes of freight the porters would also use equipment such as wheelbarrows. However, the motive power provided for this equipment still came from human beings.

Foreigners were particularly struck by the use of blacks for transporting people and freight. Thomas Ewbank, who lived in Brazil from I 845 to I 846 , said that "The whole business part of Rio is singularly well adapted for railways, and if the people determine to continue blacks as beasts of draught, it would be to their interest to have them."

The widespread use of these porters was generally seen as a consequence of the fact that most of them were escravos ao ganbo, i.e. wage-earning slaves who had to pay a fixed income to their owners at the end of the day or the week. Debret believed that the opposition to the introduction of new means of transport was directly connected to the importance of wage-earning slaves in Rio de Janeiro in the first half of the nineteenth century. ${ }^{3}$ To maintain the predominance of porterage was in the interest of the slave-owners as it meant an opportunity for economic return.

To understand the widespread use of slave labour in the Brazilian transport sector, it also helps to bear in mind the tradition of porters in Africa. In the main regions from which slaves were brought to Brazil western Africa, central western Africa, and eastern Africa - porters played a fundamental part in enabling trade between villages and cities. Europeans who traded with Africans in the interior of the continent entered into contact with these porters regularly when transporting goods. ${ }^{4}$ In Brazil, slave-owners were able to use to their own advantage a tradition that existed in Africa, by using their slaves as wage-earning porters.

As well as noting the significant economic benefits that the service provided by the porters generated for their owners, it should also be

I. Jean-Baptiste Debret, Viagem pitoresca e histórica ao Brasil [1834-I839] (Belo Horizonte [etc.], I978), p. 32 I.

2. Thomas Ewbank, Life in Brazil; or, a journal of a visit to the land of the cocoa and the palm. With an appendix, containing illustrations of ancient South American arts in recently discovered implements and products of domestic industry, and works in stone, pottery, gold, silver, bronze, etc. (New York, 1856), p. 85.

3. Debret, Viagem pitoresca e histórica ao Brasil, p. 234.

4. On the African porters, see Paulo Cruz Terra, "Relações étnicas no setor de transporte: carregadores, cocheiros e carroceiros no Rio de Janeiro (I 824-I 870)", Revista do Arquivo Geral da Cidade do Rio de Janeiro, 3 (2009), pp. 27-40; Toyin Falola, "The Yoruba Caravan System of the Nineteenth Century", International Journal of African Historical Studies, 24 (I99I), pp. II I-I 32; Roquinaldo A. Ferreira, "Dos sertões ao Atlântico: Tráfico ilegal de escravos e comercio lícito em Angola, I 830-I 860” (M.A., Universidade Federal do Rio de Janeiro, I997). 
noted that this work highly suited these slaves, even though it had been forced on to them. According to Mary Karasch, the role of porter was the favourite role of the escravos ao ganho.' Travellers' reports explain that this was because the activity allowed the slaves themselves to organize their collective labour. The members of the groups of porters, always with a leader chosen from amongst them, negotiated the tasks to be carried out and decided how large a team would be required, depending on the volume and weight of the goods. ${ }^{6}$

On occasions, the porters would also unite to buy their freedom. According to the testimony provided by J.B. Moore, Chairman of the Brazilian Association of Liverpool, to the Select Committee on the Slave Trade, porters of coffee from the Mina ethnic group would advance money to buy the emancipation of a member, and would then be paid back in monthly instalments. ${ }^{7}$ Charles Ribeyrolles, another traveller, claimed that members of this ethnic group in Rio de Janeiro constituted a corporation among themselves which put money aside to buy freedom and each year sent freed slaves back to Africa. ${ }^{8}$ It should be noted here that although these urban slaves enjoyed a certain freedom of movement, as they often carried out their activities far removed from the direct control of their owners, one of the main reasons for the creation of the police in Rio de Janeiro as early as I 808 was precisely to monitor and control the city's slave population. ${ }^{9}$

\section{FROM BLACK PORTERS TO THE FIRST VEHICLES}

Despite the major role played by black porters, mainly slaves, in the daily life of the city, there is also evidence of the existence of vehicles in Rio de Janeiro at this time. ${ }^{\circ}$ A survey of applications for vehicle licences from

5. Mary C. Karasch, "From Porterage to Proprietorship: African Occupations in Rio de Janeiro, I 808-1 850", in Stanley L. Engerman and Eugene D. Genovese (eds), Race and Slavery in the Western Hemisphere: Quantitative Studies (Princeton, NJ, 1975), pp. 369-393, 377-378. 6. See, for example, John Luccock, Notas sobre o Rio de Janeiro e partes meridionais do Brasil. Tomadas durante uma estada de dez anos nesse pais, de I808 a I8I8 (São Paulo, I942), p. 74; Debret, Viagem pitoresca e histórica ao Brasil, p. 238.

7. See his testimony cited in Manuela Carneiro da Cunha, Negros estrangeiros (São Paulo, 1985), p. 34 .

8. Charles Ribeyrolles, Brasil Pitoresco (Belo Horizonte [etc.], 1975), pp. 208-209. Porterage had, of course, its hideous side too. Travellers' accounts give graphic descriptions of bodily deformities among black porters caused by the excessive weight carried.

9. On the formation of the police at the beginning of the nineteenth century, see Leila Mezan Algranti, O feitor ausente - estudo sobre a escravidão urbana no Rio de Janeiro (Petrópolis, 1988); Thomas Holloway, Policing Rio de Janeiro: Repression and Resistance in a NineteenthCentury City (Stanford, CA, I993).

Io. For the transport history of Rio de Janeiro see Francisco Agenor de Noronha Santos, Meios de transporte no Rio de Janeiro (bistória e legislação), 2 vols (Rio de Janeiro, I934); Charles 
the city authorities shows that $62 \mathrm{I}$ such licences were requested in the first half of the nineteenth century. ${ }^{\text {II }}$ In my research of the documentation, I found requests for licences for tilburies, luxury carriages, and four-wheeled carriages. However, the great majority of submissions for licences were for carts, which accounted for 83.89 per cent of the licences granted.

In many of the requests for licences made to the City Council, the uses of the carts concerned were indicated. These included the transport of firewood and furniture, the provision of removal services, and the delivery of agricultural produce to markets. A large proportion of the carts were used to provide basic urban services such as the delivery of barrels of water and the transport of waste water, basically sewage. There were also carts used to transport waste from individual residences to designated sites for disposal.

It is important to note here that the functions carried out by means of these carts were practically the same as those carried out by the black porters. However, the methods of transport were very different. The carts were pulled by animals, whereas the porters generally transported their goods on their shoulders or even on their heads. There was another major difference referring to the workforce behind the two modes of transport: while the porters were mainly slaves, with a minority of free men among them, the cart drivers were nearly all free men, many of them immigrants from Portugal. ${ }^{\mathrm{I}}$

The presence of these vehicles in the transport of freight and people in the first half of the nineteenth century provides us with evidence for the beginning of a process of segmentation and the establishment of a hierarchy in the transport sector, a process that was also developing on a wider scale in the general labour market in Rio de Janeiro. Slaves and free men, Brazilians and immigrants, shared working spaces every day factories, shops, and streets - and often disputed work positions. Free men secured the best positions for themselves, and in the transport sector this meant that they represented the clear majority of the drivers of vehicles. Meanwhile, the manual transport of freight and people was

Julius Dunlop, Os meios de transporte do Rio antigo (Rio de Janeiro, 1973); and Maria Laís Pereira da Silva, Os transportes coletivos na Cidade do Rio de Janeiro: tensóes e conflitos (Rio de Janeiro, 1992).

I I. Vehicle owners were required to apply for a licence from the city authorities. The licences issued from 1837 to 1870 were consulted in the Arquivo Geral da Cidade do Rio de Janeiro (AGCRJ), Códices 51.1.17, 57.4.10, 57.4.13, 57.4.15, 57.4.17, and 57.4.20.

I 2. For the period between I 824 and I 870 , the analysis of licences to work ao ganho, licences for vehicles, and the House of Detention's documentation show that for the porter function only I.I per cent consisted of free workers, while 98.9 per cent were enslaved. In relation to the coachmen and carters, free workers accounted for the overwhelming majority (95.4 per cent). Among those identified as coachmen and carters, the Portuguese represented 56.2 per cent of all free workers. 
carried out mainly by slaves, the black porters. This process of segmentation and increased hierarchy became more accentuated in the second half of the nineteenth century. There was a sharp rise in the number of vehicle licences awarded from I8 5 I to I 870 , reaching a total of 2,477 licences. Free workers, including Portuguese immigrants, continued to represent the majority of the drivers of these vehicles. Carts assumed an even greater role in the transport of freight in the streets of Rio de Janeiro and in the daily life of the city.

The number of Portuguese in the transport sector is related, firstly, to the large number of immigrants who came from Portugal, which was already considerable in the first half of the century and grew further after I 850 . The Portuguese comprised about ro per cent of the inhabitants of Rio de Janeiro in 1849 , a figure that reached 20 per cent of the total population in 1872 , making up 66 per cent of foreigners. ${ }^{\mathrm{I}}$ Secondly, the strong presence of Portuguese immigrants among transport workers can be related to the fact that they already had contact with the same vehicles in their homeland. ${ }^{\mathrm{I}}$ In the Rio de Janeiro context, driving vehicles was one way that these Portuguese immigrants found to differentiate themselves from slave workers, with which the figure of the black porter was commonly associated. For those who came with some savings, or who acquired them in Brazil, the low initial cost of buying a cart and animals meant that the transport sector was an attractive option for "immigrants who came here and had little money to start a small business". Is

Although carts had taken over much of the activities previously performed by porters, the porters had by no means disappeared. For part of the second half of the century, cart drivers and porters would continue to coexist. According to Karasch, the porters protested when tradespeople began to replace them by horses and carts, depriving them of the income opportunities mentioned above. ${ }^{16}$ As the records show, the introduction of new means of transport was generally not an automatic or natural process. On the contrary, it led to competition, disputes, and open conflict between the workers. Over the course of the second half of the

I3. Luiz Felipe de Alencastro, "Proletários e escravos: imigrantes portugueses e cativos africanos no Rio de Janeiro, I850-I 872", Novos Estudos, 2 I (I988), pp. 30-56, 54.

14. On transport in Portugal, see Terra, "Relações étnicas no setor de transporte"; Artur Teodoro de Matos, Transportes e comunicações em Portugal, Açores e Madeira (I750-I850) (Ponta Delgada, I980); Fernando Galhano, O carro de bois em Portugal (Lisbon, I973); Guido de Monterey, O Porto. Origem, evolução e transportes (Porto, 1972).

I s. Elciene Azevedo, "A metrópole às avessas: cocheiros e carroceiros no processo de invenção da 'raça paulista", in idem et al. (eds), Trabalhadores na cidade: cotidiano e cultura no Rio de Janeiro e em São Paulo, séculos XIX e XX (Campinas, 2009), p. 91. The author's considerations regarding the São Paulo context are also valid for analysing the decision of Portuguese immigrants to opt for the transport sector in the case of Rio de Janeiro. All translations from Portuguese into English are my own.

16. Karasch, "From Porterage to Proprietorship", pp. 377-378. 
century, the black porters would witness how their operations were gradually restricted to the transport of freight within the port area. Moreover, although they continued to form the major part of the workforce in the port, they also had to face increasing competition from free workers, many of whom, again, were Portuguese immigrants. ${ }^{17}$

In May 1872, a group of black porters who worked at Praça das Marinhas and were escravos ao ganbo demanded a pay rise from the service contractors. These contractors called on white workers, probably Portuguese, who agreed to provide the service for a lower price. However, the group of black porters got together and physically abused the white workers, throwing some of them in the water. ${ }^{18}$ This case is but one example of how free and unfree work was closely connected in Rio de Janeiro in the nineteenth century. The fact that escravos ao ganbo were paid, as Marcel van der Linden has noted, shows that the boundaries between concepts such as "slavery" and "wage labour" could be extremely confusing. Further, "the wage laborers are often less 'free' than the classic view suggests". ${ }^{19}$ In this sense, as Alessandro Stanziani has shown, for the majority of European countries between the sixteenth and the end of the nineteenth century "the barrier between freedom and bondage was not only moveable and negotiable, it [was] also thought of differently from how we are used to thinking of it today". This author noted that "labour was submitted to serious legal constraints, usually justified by reference to the 'debt' or the 'deed' the worker, or the peasant, had contracted with both master and community". ${ }^{\circ}$

In the case of Brazil in the nineteenth century, things were not very different, and it was possible to find former slaves who had signed service contracts promising to repay through years of work the loan of a certain amount which had usually been used to buy their own manumission. Although they were no longer slaves, they promised to serve their employer with obedience. ${ }^{21}$ However, it was not only former slaves who

17. Compared to other areas of Rio de Janeiro, the proportion of blacks found among those labouring in the port was higher. Yet the proportion of whites, including many Portuguese, was significant. According to Erika Bastos Arantes, among longshoremen in the House of Detention between I $90 \mathrm{I}$ and 191029 per cent were white, 32.6 per cent were black, and 28.5 per cent mulatto; Erika Bastos Arantes, "O Porto Negro: cultura e associativismo dos trabalhadores portuários no Rio de Janeiro na virada do XIX para o XX” (Ph.D., Universidade Federal Fluminense, 2010), p. 76.

i8. Jornal do Commercio, 5 March i8 72.

19. Marcel van der Linden, Workers of the World: Essays Toward a Global Labor History (Leiden [etc.], 2008), p. 23.

20. Alessandro Stanziani, "The Legal Status of Labour from the Seventeenth to the Nineteenth Century: Russia in a Comparative European Perspective", International Review of Social History, 54 (2009), pp. 359-389, 388.

2 I. Henrique Espada Lima, "Sob o domínio da precariedade: escravidão e os significados da liberdade de trabalho no século XIX”, Topoi, 6: I I (2005), pp. 289-326, 305. 
were subjected to such situations. Many Portuguese came to Brazil as engajados, a condition similar to that of the indentured servants who arrived in the eighteenth century in the West Indies and North America. ${ }^{22}$ In return for the costs of transport by sea, the engajados were charged twice the regular fare. They could land in Brazil only with the permission of the boats' captains. In Brazilian ports genuine auctions of men and women took place, very similar to the auctions of African slaves. Local recruiters paid the ticket and those who desired to contract the services of immigrants were charged a higher sum then paid by the recruiters. ${ }^{23}$ Then, a service contract was drawn up which subjected the engajados to payments lower than those received by other workers, such as the amount paid to rent a slave. It was possible to find in the newspapers advertisements concerning engajados who had run away from their place of work before the end of the contract period, very similar to the runaway slave advertisements. ${ }^{24}$

The changes that took place in the transport sector in Rio de Janeiro, which went from being a city in which freight was carried by black porters to one in which carts predominated and then to a city of trams, have often been seen as a consequence of urban growth. For example, according to Ana Maria da Silva Moura, the increase in the city's population and production from I 849 to I 856 led to a larger market for the carts and also to a greater need to distribute both imported and domestically produced goods. ${ }^{25}$ However, this process of transformation cannot be reduced to a direct equation between population growth and the growth in the number of carts without taking into account several other key variables that were at work at this time. Although the demographic data for Rio are problematic, they do show that the city's total population grew only slightly between I 849 and I 872 , from 266,466 inhabitants to 274,972 , a growth of just over 3 per cent. In the same period, the number of vehicles increased by almost 300 per cent. Clearly, population growth by itself cannot explain this increase.

The main difference between the census of 1849 and that of 1872 was in the number of slaves, which fell dramatically in the capital in this period. From representing 4I.5 per cent of the city's total population in I 849 , when Rio de Janeiro had the largest population of slaves of any city in the Americas, by 1872 the slave population had fallen to just 17.8 per cent of

22. Alencastro, "Proletários e escravos", p. 36.

23. Miriam Halpern Pereira, A política portuguesa de imigração (Lisbon, 2002), p. 37.

24. Artur José Renda Vitorino, "Mercado de Trabalho e Conflitos Étnicos em Meio à Escravidão: portugueses e africanos no Rio de Janeiro, I850-1870", Cadernos Arquivo Edgard Leuenroth, 27 (2009), pp. I I-57, 29.

25. Ana Maria da Silva Moura, Cocheiros e carroceiros: homens livres no Rio de senhores e escravos (São Paulo, 1988), p. 42. 
the inhabitants. ${ }^{26}$ According to Karasch, the reasons for this decrease included high mortality rates in the early I850s and an increase in the price of slaves (because of the prohibition of the slave trade in I850 and the demand for labour from coffee plantations), both of which led many slave-owners either to rent or sell their slaves to rural areas. ${ }^{27}$

The opposition to the introduction of other means of transport came mainly from the slave-owners, who were concerned by the impact on the economic opportunities of their wage-earning slaves who were working as porters. The relative decline in the slave population surely contributed towards rendering this kind of opposition obsolete.

I 850 is also considered to have been a watershed year for the Brazilian economy in general. The end of slave trading in that year released capital that had previously been employed in this activity. This enabled an "increase in the liquidity of the economy, a diversification of investments, and the start of financial activities to be deployed in the service sector and the nascent industrial sector" ${ }^{28}$ If before I 850 Brazil had barely responded to the rise of international capitalism, Maria Bárbara Levy has shown that following that year the country was able to draw up its own legal framework for a company law, enabling the establishment of the sociedade anonima or the limited liability company. ${ }^{29}$ The freight and passenger transport companies that sprung up after i 850 were hence clearly related to this process of the wider transformation of the Brazilian economy, which supported the establishment of new forms of companies.

Several companies were established specifically in the freight transport sector, which promised very high profits. The importance of this sector is related to some of the basic characteristics of Rio de Janeiro in the nineteenth century, when it was both the capital of the country and the main port for exporting coffee, the most important product of the Brazilian economy. ${ }^{30}$ As a result, the port of Rio de Janeiro generated enormous demand for freight transport services.

Commercial and industrial facilities also began to develop their own fleets of vehicles and to hire workers to drive them. Many advertisements for drivers can be found in newspapers of the time, such as that placed by a timber warehouse in Rua da Saúde, which in 1873 advertised for a driver

26. Sidney Chalhoub, Visões da liberdade: uma história das últimas décadas da escravidão na corte (São Paulo, I990), p. I99.

27. Mary C. Karasch, A vida dos escravos no Rio de Janeiro (I 808-I850), (Säo Paulo, 2000), p. 28. 28. Elisabeth von der Weid, "A cidade, os bondes e a Light: caminhos da expansão do Rio de Janeiro (I850-19I4)” (Ph.D., Universidade Federal Fluminense, 2010), p. 49.

29. Maria Bárbara Levy, A indústria do Rio de Janeiro através de suas Sociedades Anônimas. Esboços de história empresarial (Rio de Janeiro, 1994), p. 52.

30. Eulália Maria Lahmeyer Lobo, História do Rio de Janeiro (do capital comercial ao capital industrial e financeiro), 2 vols (Rio de Janeiro, I978), II, p. 47. 
and offered to "pay a good wage". ${ }^{31}$ Carts and their drivers had a presence in almost all the city's businesses, from breweries such as Brahma to laundries, textile companies, mills, factories for soap and sails, brickmakers, and others. ${ }^{32}$ Cart drivers were responsible for transporting nearly all the goods produced and sold within the city.

In the area of passenger transport, since the beginning of the nineteenth century the city had been home to establishments that rented out carriages and chaises. In 1859 , donkey-drawn trams were introduced in Rio de Janeiro, which was the first city in South America to have this type of transport. By the end of the century, there were four main companies in Rio de Janeiro providing tram transport on rails: Companhia Jardim Botânico, in the southern zone of the city; Companhia Carris Urbanos, in the centre; and Companhia Vila Isabel and Companhia de Carris da Tijuca, both in the north.

In this period, the tram became the main means of transport for passengers in Rio de Janeiro. From I870 to I905, the number of users increased by over I,680 per cent, rising to more than 100 million passengers in 1905. The number of passengers using the trams was significantly higher than the number of passengers for other forms of transport. For example, from i 886 to I 896 the Estrada de Ferro Central do Brasil, a railway company which connected the centre of the city with the suburbs, transported 30 million people in total, while in I 896 alone the number of tram passengers reached almost 73 million people.

\section{WORK AND DISCIPLINE IN THE TRAM COMPANIES}

As we have discussed, the establishment of the first tram companies was closely associated with the economic transformations taking place in Brazil. But what did the creation of these companies mean for the workers involved, and what was it like to work for them? There was a clear division of labour at the tram companies: the coachmen were responsible for driving the trams, while the conductors collected the fares. As the conductors received part of the companies' earnings, the transport companies created a network to monitor their employees. There was constant suspicion on the part of employers that the conductors were pocketing the fares. For example, the Gazeta de Noticias, a newspaper of general circulation, of 27 August I 898 stated that employees who stole these sums were disloyal as the fares represented "remuneration for the work and for the capital of the company", and were also the source of investment in improving the tram service. ${ }^{33}$

31. Jornal do Commercio, 23 May i 873 , p. 7.

32. De Noronha Santos, Meios de transporte no Rio de Janeiro, II, p. 26.

33. Gazeta de Noticias, 27 August I898, p. I. 
The companies were also worried that they were losing money because of conductors not collecting the fares in all cases. An employee of Jardim Botânico received a letter of dismissal from the company's chairman telling him that he had already been warned that he was taking too many nonpaying passengers and, as the company could not carry all these people for free, that the employee had become "too expensive for the Company as a conductor". ${ }^{34}$ The letter illustrates how the company tried to control the revenues from the vehicles. It also demonstrates that despite the company's best efforts to monitor the service the workers had found ways to avoid these controls and to take passengers without collecting fares.

The monitoring of the conductors was carried out by inspectors, who were the companies' eyes on the ground. On I August 1903, the workers' journal $A$ greve argued that the employees of the transport companies were being victimized by capitalism, and "persecuted by these vandals and exploiters of their sweat". The newspaper said that the inspections formed a key part of the policy of the company owners, and that the inspectors were robbing the conductors of their daily bread in order to earn the good graces of the bosses. ${ }^{35}$ In 1898 , the generalized suspicion against conductors and the concern of the transport companies to maximize their profits led one transport company, Companhia Carris Urbanos, to install a system in its trams designed to ensure that fares were paid correctly. The system was based on calculating the average passenger traffic of a particular line. If this level was not reached, conductors were obliged to make up the difference from their wages. ${ }^{36}$

Over time, the monitoring of conductors and of transport workers in general intensified and company owners introduced secret inspections. These took place when there were suspicions about a particular employee. To catch the suspect in the act, the inspections were carried out by unidentified inspectors who were not known to the employees. However, the employees were given no right of defence and were only alerted when they received letters fining them or dismissing them from the company. ${ }^{37}$ Relations between inspectors and conductors were tense, as the former had the power to reduce the salaries of the conductors by recording any misdemeanours and even to have them dismissed. According to A greve, in its I August 1903 edition, the inspectors' director of the Companhia Jardim Botânico required conductors, through his assistants, to provide him with valuable gifts, such as cases of port wine, and threatened conductors who refused with dismissal. ${ }^{3}$

34. Charles Julius Dunlop, Apontamentos para a bistória dos bondes no Rio de Janeiro, 2 vols (Rio de Janeiro, I953), II, p. 3 I.

35. A greve, i August 1903, p. I.

36. Gazeta de Noticias, I6 March I898, p. I.

37. A greve, I August 1903, p. I.

38. Ibid. 
Coachmen had to comply with schedules of working hours and shifts. The inspectors were responsible for verifying the coachmen's compliance with the working hours established by the employers. The coachmen worked in shifts, with the first shift starting at 3.30 in the morning. The workers' journal Gazeta Operária, in its edition of 8 February 1903, said that employees of the tram companies had wages that were "negligible considering they worked twelve, fourteen, or even more hours per day". ${ }^{39}$ By way of comparison, in Berlin in 1902 coachmen and conductors generally worked eleven hours a day, and a maximum of twelve hours. ${ }^{4}$ A manifesto from the coachmen of Lisbon, dated i9io, says that "by day they work from seven in the morning to seven at night, and by night from eight until the morning, in the cold and the rain". ${ }^{\mathrm{I}}$ Average working hours for employees of tram companies in Rio de Janeiro were generally the same as in other cities around the world, although they could be extended. Coachmen and cart drivers who worked for other transport companies outside the tram sector might work even longer hours. In I906, the working day in the transport sector was "fourteen, sixteen, or more hours per day, beginning in the morning and going on until late at night". In December that year, transport workers went on strike, demanding a working day of twelve hours. ${ }^{42}$

The companies imposed a range of regulations on their employees. These established the respective punishments that could be inflicted, including fines, suspension, and dismissal. These rules were mandated by the employers, who were also responsible for ruling on each case. According to Carlos da Fonseca, such fines have to be regarded, in general, as "the everyday expression of employer justice, and a sort of purgatory of small offences". ${ }^{43}$ These regulations were common not only in transport companies in Rio de Janeiro but also in other countries, including Portugal. By the end of the nineteenth century such regulations had become common practice in different types of Brazilian companies. According to Robério Santos Souza, company regulations "were established as an increasingly wide-reaching set of rules and norms, which covered areas ranging from moral teaching for employees to information about wages, fines, suspensions, and the management of conflicts". ${ }^{44}$

39. Gazeta Operária, 8 February 1903, p. 3.

40. John P. McKay, Tramways and Trolleys: The Rise of Urban Mass Transport in Europe (Princeton, NJ, 1976), p. 233.

41. O Sindicalista, 27 November 1910, p. 3.

42. Gazeta de Notícias, i7 December 1906, p. I.

43. Carlos da Fonseca, História do movimento operário e das ideias socialistas em Portugal, 4 vols (Lisbon, I980), IV, p. 6.

44. Robério Santos Souza, "Organização e disciplina do trabalho ferroviário baiano no pós-abolição", Revista mundos do trabalbo, 2:3 (2010), pp. 76-98, 76. 
Company regulations also constituted disciplinary mechanisms in which employers established their expectations for the performance and behaviour of their workforce.

From 1903 the rules of the Companhia Jardim Botânico required conductors and tram drivers to buy uniforms from a related company. The journal $A$ greve said that at this company each uniform cost 50,000 réis "from a very ordinary factory", "while other companies" provided them to their employees for just 37,000 réis. ${ }^{45}$ Complaints about companies forcing their employees to benefit related parties can also be found in letters from the coachmen of Companhia São Christovão to the journal A Reforma in I873. According to the coachmen, company management required employees to use a metal badge on their caps. Although the coachmen had repeatedly called for this to be "replaced by any other form of emblem, the management paid no attention, perhaps because they were afraid of damaging the interests of the metal manufacturer, which are looked after by a well-known director at the company". ${ }^{46}$ We should also note that one of the reasons for the workers' rejection of the metal might have been that metal insignia were used by wage-earning slaves. Most employees of the tram companies were free men, and in Rio de Janeiro in the second half of the nineteenth century their refusal to use the metal could well have been connected with their unwillingness to be identified with slave workers. The coachmen of São Christovão also complained that company employees had to pay I,000 réis a month to a doctor, although most of them already had doctors and mutual societies for medical treatment. The workers warned that if their demands were not met, the company would end up with no employees, as many of them were determined to leave the firm. ${ }^{47}$

The obligation on workers to buy their uniforms and badges from specific providers, or to pay for a medical service they did not want, suggests that relations between employers and employees were not limited only to the simple remuneration of their labour. Marcel van der Linden argues that ties were possible "between both parties outside the circulation process", and that the employers had ways of binding their employees to them. ${ }^{4}$ As mentioned before, wage labour was often less "free" than has been assumed.

It can be seen from this survey that the hours worked by employees and their earnings were subject to intense controls by the transport companies,

45. Ibid. In 1910 motormen and conductors of the Light Company in São Paulo complained that they, too, were forced to buy their uniforms for twice the normal price; João Marcelo Pereira dos Santos, "Os trabalhadores da Light São Paulo, I900-1935" (Ph.D., Universidade Estadual de Campinas, 2009), p. 146.

46. A Reforma, 22 January i 873 .

47. Ibid.

48. Van der Linden, Workers of the World, p. 29. 
and that strategies for these controls evolved over time. In addition, systems for fines, suspensions, and dismissals aimed to punish employees and to establish rules and hierarchies, as well as to maximize exploitation of the workers.

\section{CONFLICTS AND THE REGULATION OF THE TRANSPORT WORK}

In addition to the inspection practices at the companies themselves, which became more sophisticated over time, transport workers were also governed by an extensive system of laws and rules designed to control them. This was related to some of the inherent characteristics of the profession: coachmen and conductors worked far from the eyes of their employer, they were much more mobile than any other group of industrial workers, and they had direct and daily contact with the population. ${ }^{49}$ Another important point is that, despite the importance of companies in the transport sector, there were still self-employed workers engaged in transporting people and freight, such as waste. In this sense, the laws and regulations also aimed to control workers who were not subject to company rules and punishments.

In 1853 , the City Council of Rio de Janeiro passed the first specific laws aimed at the drivers of vehicles. These laws required all coachmen to register with the police and to take an examination to prove their vehicledriving skills. Later, in December I 872, the City Council signed a contract with Nunes de Souza \& Cia, according to which the company would collect waste from residences, replacing around $\mathrm{2} 20$ cart drivers who had provided this service independently. Over the course of 1873 , this contract became highly controversial, with opposition to it led by Luiz Fortunato Filho, the lawyer representing those workers who had provided the service before the contract was announced. In various letters to newspapers and in submissions to the relevant authorities, he alleged that the company would have, in fact, a monopoly over the service, in breach both of the freedom of trade and the freedom of the residents themselves to choose people that they trusted to provide the service. ${ }^{50}$

As a way of making their decisions effective, the local authorities then halted the provision of licences to the waste collectors and seized the vehicles of those cart drivers who continued to work. Faced with the quantities of waste piling up in the streets - partly because the licensed company could not cope with demand and partly because some residents refused to use the company's services - the city authorities subsequently

49. Anton Rosenthal, "Streetcar Workers and the Transformation of Montevideo: The General Strike of May igi I", The Americas, 5 I (1995), pp. 47I-494, 479.

50. See, for example, Jornal do Commercio, 22 February i 873, p. 2. 
decided to hand out licences to the cart drivers again. The cart drivers then refused to go back to work, on the grounds that the licences were conditional and could be withdrawn at any time. A strike was organized with the aim of forcing the authorities to guarantee them their right to work. ${ }^{5}$ The Ministry of Business of the Brazilian Empire then issued a ruling indicating that, as the company did not have the materials necessary to carry out the contract, the licences to the cart drivers should be maintained..$^{2}$ The cart drivers decided to return to work.

Ultimately, the company could not comply with the terms of the contract, and the cart drivers continued with their trade. However, in I875 the city authorities approved a series of rules for carts which collected waste from the city's streets and houses to tighten controls on the workers involved. These rules included establishing sites where the cart drivers could dispose of the waste and the model of cart that could be used; they also stated that the service could be carried out "only until 9 o'clock in the morning, in the months of October to March, and until io o'clock, from April to September". The penalty for breaking any of these rules was a fine of 30,000 réis and "eight days in prison, to be doubled for repeat offenders". ${ }^{33}$

In February I 876 the authorities also published a decree that required rigorous compliance with the times it had stipulated for collecting waste. The workers considered this attitude and the fines to be excessively harsh, and also noted that their carts could be confiscated and impounded without there apparently being any legal basis for this. These grievances, combined with the decision to restrict the waste collection service to the morning, resulted in a second strike by the cart drivers. Luiz Fortunato Filho argued that the right to work was at stake in this new dispute. The cart drivers who carried out waste collection services were mainly selfemployed workers, and the press emphasized this fact in their support of the workers. The Gazeta de Noticias of is February i 876 asked:

Does the City Council have any contract with the cart drivers who collect the waste from individual residences? Does it provide them with any guarantees? No, it forces them to pay for a licence [...] with taxes, fines, prison, and the pound.

How can it expect to impose laws on free men, who have to be able to work if they want? How can it impose a duty on those workers to whom it gives no rights? ${ }^{4}$

For the workers, the service they provided would not have been advantageous under the conditions imposed by the City Council. The workers said that they were not responsible for ensuring the health and hygiene of the city 
and that they worked to earn their daily bread: "[I]f they want us to continue to work as we have in the past, we will: if not, we will not return to work." "s The strike was reported widely in the press, as the waste left uncollected at residences was associated with concerns over the rising number of deaths from yellow fever. At this time, the waste accumulation was considered one of the causes of the outbreaks of yellow fever in 1873 and 1876 , which claimed 3,659 and 3,476 lives respectively. ${ }^{56}$ In both years, the workers responsible for waste collection had considerable bargaining power.

The clear support of the press, the waste that was piling up in the streets, and the spike in yellow fever cases led to yet another victory for the workers. According to the Revista Illustrada of I9 February I876, "finally the City Council, the Police, and the Ministry had to respond to the noble class of cart drivers" and the contested rulings were overturned. ${ }^{57}$ Not surprisingly, just after the end of the strike, the defeated City Council again discussed the possibility of giving a company a monopoly over the collection of domestic waste. It was more important than ever for the authorities that the service should not remain in the hands of the cart drivers who had repeatedly defeated them, and who had been able to block the City Council's attempts to control and even abolish their work.

With regard to the carters who collected waste, the 1873 strike was an attempt by workers to stop the increasingly aggressive process in the city whereby workers would no longer own their instruments of production. In I 897, the city government, finally, signed another contract with a company and carters were no longer allowed to carry out their traditional work. Although the company acquired a monopoly of domestic waste collection, it is possible to identify the enduring persistence of the selfemployed in other spheres of the transport sector, albeit in small numbers.

Transport workers also saw themselves affected by (and acted against) the introduction of certain more general laws. In 1890 , following the Proclamation of the Republic in I889, workers in the urban transport sector went on strike to protest against the Penal Code of i I October I 890. Most of Rio de Janeiro's newspapers claimed that the coach drivers and cart drivers were complaining about provisions that were not, in fact, included in this new Code. For example, the Jornal do Commercio, a newspaper of general circulation, claimed that the workers' allegations were not founded on facts and must have been maliciously invented by "wretched speculators who thrive on the simplicity of the workers", and who manipulated the "placid spirits of these poor coachmen".58

55. Ibid.

56. Sidney Chalhoub, Cidade febril: cortiços e epidemias na Corte imperial (São Paulo, I996), p. 86.

57. Revista Illustrada, i9 February I 876.

58. Jornal do Commercio, 2 December i 890 , p. I. 
One dissenting voice, however, was that of the Gazeta da Tarde, in its 2 December 1890 edition. The newspaper said that a commission formed by transport workers had gone to the newspaper to explain that their protest was not as unjustified "as is generally believed[;] even if the item that was discussed at such length yesterday does not in fact exist, there are in the legislative reform of Mr Campos Salles some draconian proposals and it is against these proposals that the cart drivers are protesting". 59 The commission from the workers cited in particular two of the articles in the Code, addressing the issue of punishment for accidents.

The evidence that the workers sent a commission to the newspaper casts them in a new light, not as helpless and simple souls manipulated by forces that were using them for their own purposes, but as people with clear, conscious demands, who knew exactly what they were fighting for and who they were fighting against. By specifically citing the articles in the Code that they were opposing, the workers were able to rebut the accusation made by the Diário de Noticias newspaper that they were not really protesting against the Penal Code, "mainly because the Code is almost unknown, even to educated people in the country". ${ }^{60}$

Although various newspapers argued that the offending article in the Penal Code relating to accidents did not apply only to coachmen and cart drivers, these workers understood that it did directly affect them. There were constant accidents involving their vehicles, and these accidents were one of the major points of conflict between drivers and passengers, with drivers widely caricatured and attacked in the press. In I 890 a child had been run over, leading to significant tension and protests from the population. ${ }^{61}$ In this context, the vehicle drivers were well-advised to be concerned about any new law on accidents that would also apply to them.

As well as claiming that workers were being manipulated in the strike, some of the press also questioned the reasons for the walkout. According to the Diario de Noticias, "in every corner of the world the criminal code contains punishments for all kinds of crimes and there were never strikes against the law upheld by their governments". ${ }^{62}$ The Jornal do Commercio argued that "a workers" strike aims either to right a wrong or to achieve an increase in pay. However, in this strike, the cart and coach drivers have no determined goal at all." ${ }^{\prime 3}$ The line of argument in these newspapers was, thus, that opposition to a particular law or ruling generally was neither a normal nor a sufficient ground for a strike.

59. Gazeta da Tarde, 2 December I 890 , p. 2.

60. Diário de Noticias, 3 December I890, p. I.

6r. Ibid., I 4 July i 890 , p. I.

62. Ibid., 2 December I890, p. I.

63. Jornal do Commercio, 4 December I890, p. I. 
However, some newspapers provided their readers with a different version of events. The Gazeta da Tarde explained why the coachmen had gone on strike in the following way, offering an interesting interpretation of the relationship between the strikes and the law:

Since the right of law was replaced by the right of force; since at every moment the law and administrative procedures are disparaged; since the people are represented by a congress full of appointees, without the authority to carry out justice or to right wrongs; since the people are convinced that the laws imposed on them do not reflect the will of the people but that of a cabal that keeps itself in power by force alone, and that these decrees and rules serve only to support interests that cannot always be disclosed, the one brake on popular unrest that exists along with religion, has disappeared - respect for the law has disappeared. ${ }^{64}$

In I 899, new rules were established for inspecting vehicles. These consisted of the most detailed document ever produced at that time for controlling transport workers. These rules proved to be the trigger for the strike that started on is January 1900. The Gazeta de Noticias noted that the walkout was a consequence of a lack of clarity on the part of the police concerning the technical details of these new regulations. According to the newspaper, it was, for instance, incomprehensible that the police had made no statement about the rumours circulating that the coach drivers would have to be photographed. ${ }^{65}$ Although the government said that the mandatory photograph requirement was only a rumour, the Jornal do Brasil, a newspaper of general circulation known to be concerned with workers' conditions, then found out that for the coach drivers it was, in fact, a real obligation, even though it did not appear in the new regulations. The workers alleged that several companies, such as São Christovão, had published rules requiring a photograph of the worker to be taken, and that vehicle inspectors were also requiring photographs.

But why did the workers protest so strongly against being photographed by the police? As all the newspapers of the time explained, until then it was only thieves whose photographs were taken by the police. A member of the police anthropometry service wrote that the photographs were used for purposes of identification, so that the suspects could not use any name they desired. ${ }^{66}$ When they learned that they would be photographed compulsorily, the drivers believed they were being equated with common thieves. Their demand for the requirement to be dropped was closely connected to the symbolic aspects of the requirement for a police photograph, which represented the tightening of police control over the workers. 
Following the end of the transport workers' strike, on 17 January the Beneficial Society for the Protection of Coachmen delivered a document to the Ministry of Justice containing the demands of its members. This document also protested that coachmen were being charged fees for licences that were higher than the amounts that had been set. In addition, the coachmen complained about certain provisions of the rules, such as Article 36, which covered the impounding of vehicles. The document alleged that it was unfair that coachmen and cart drivers were to be doubly punished: in addition to having their licences confiscated the seizure of their vehicles would lead to further expenses for recovering them from the pound. ${ }^{67}$ The workers were successful. On 20 January, the Minister of Justice, Epitácio Pessoa, issued a decree that accepted all the amendments requested in the submissions lodged by the Beneficial Society for the Protection of Coachmen. ${ }^{68}$

The laws and regulations cited in this article indicate the concern of the institutions of the state with controlling transport workers, workers who, as mentioned above, formed a constant presence in the public space and had direct and daily contact with the population. The relationship between passengers and transport workers could be very contentious, especially with regard to the frequent vehicular accidents. The causes of such accidents were widely discussed in the press, impunity being considered the major contributor to the large number of cases. The population demanded that the government act vigorously, and the regulations and laws reflected this demand too. ${ }^{69}$ The forms of control were tightened over time in Rio de Janeiro, with increasingly detailed regulations, while at the same time they were adapted to the technological transformations of the sector, such as the specific regulation created to cover electric trams, which arrived in the city in 1892 .

It was not only in Rio de Janeiro that transport workers were the subject of extensive laws and that these measures constituted an important trigger in their strikes. In Lisbon, two out of three stoppages organized by transport workers in the nineteenth century were linked to laws approved by the City Council. In turn, in April I 899, the coachmen of Buenos Aires went on strike to protest against the City Council's decision to require them to have a photograph taken in order to get a driver's licence. ${ }^{70}$

67. Jornal do Commercio, i9 January i900, p. I.

68. Relatório apresentado ao Presidente da República dos Estados Unidos do Brasil pelo Dr Epitácio Pessôa, Ministro de Estado da Justiça e Negócios Interiores em Março de 1900 (Rio de Janeiro, I900), p. I63.

69. Diário de Notícias, 7 July i 890 , p. I.

70. Mercedes García Ferrari, “Una marca peor que el fuego'. Los cocheros de la ciudad de Buenos Aires y la resistencia al retrato de identificación", in Lila Caimari (ed.), La ley de los profanos: delito, justicia y cultura en Buenos Aires: 1870-1940 (Buenos Aires, 2007), p. I 26. 
For their part, the transport workers had their own readings and interpretations of these measures and demonstrated their response in actions such as the series of strikes that have been analysed in this article. In their reactions, the workers challenged "the law as an instrument of power of dominant groups", and made use of the "legal resources available to defend their rights and subvert the original purpose of the legal codes, which was to serve the interests of the ruling elites". ${ }^{71}$ Their struggles against new laws also show just how well the coachmen and cart drivers understood that strikes represented an effective means of restricting the actions of the dominant classes. ${ }^{72}$

\section{CONCLUSIONS}

Over the course of this article it has been shown how the urban transport sector in Rio de Janeiro underwent major changes in the nineteenth century. Many scholars have analysed these transformations in terms of the various technologies involved. Here, however, I have tried to present a different perspective, focusing on the direct impact of the changes on the workers involved, most notably on how those changes transformed the city from one that relied mainly on slave porters for its freight transport to one that used vehicles driven largely by free workers. The introduction of new means of transport and the transformation of the workforce caused competition and ethnic conflict. Further, in Rio de Janeiro in the nineteenth century the barrier between free and unfree labour was very diffuse and confusing.

The establishment of the first major transport companies in the city was directly connected to the transformation of the Brazilian economy in general. Labour in these companies was subject to strict controls, regulations, and inspections, as this was a sector in which workers travelled all over the city and spent much of their working day far from the eyes of their employers. Coach drivers and cart drivers, company employees and self-employed workers alike, were also subject to various laws and regulations emanating from the City Council and the police.

Faced with these transformations in their sector, transport workers were by no means passive. Indeed, they were much more active than is supposed in the only study to date on Rio de Janeiro's coach drivers and

7I. These statements were made by Juliana Teixeira Souza about the small traders in imperial Rio de Janeiro; Juliana Teixeira Souza, "Do usos da lei por trabalhadores e pequenos comerciantes na Corte Imperial (I870-I880)", in Azevedo et al., Trabalhadores na cidade, p. 2 I 8.

72. A number of studies examining the relationship between workers and laws and rights have recently been added to the Brazilian historiography. See, for example, Silvia H. Lara and Joseli Maria Nunes Mendonça (eds), Direitos e justiças no Brasil: ensaios de História Social (Campinas, 2006); and Larissa Rosa Corrêa, A tessitura dos Direitos: patrões e empregados na Justiça do Trabalho (São Paulo, 20I I). 
cart drivers, authored by Ana Maria da Silva Moura. ${ }^{73}$ In my research, I found that these workers made various submissions to different state institutions about the changes, protested in their places of work, and organized a number of strikes. Of the fifteen stoppages organized by the urban transport workers of Rio de Janeiro over the course of the nineteenth century, nine were linked to questions of remuneration, either to protest for higher wages or to demand the payment of outstanding wages. The main motives for four of the remaining strikes (which this article has analysed) were provided by new laws and police regulations. These were supported by a solid majority of the workers. The strikes organized by the coachmen and cart drivers were able to disrupt an essential service in the urban space and to affect a range of other economic sectors. The strikes also enjoyed popular support and participation, often taking the form of opposition to police repression. These elements help us to understand why transport workers were the sector that experienced the highest number of strikes in Rio de Janeiro in this period. 